\title{
The Role of Political Broker: The Utilization of Botoh and Head of Villages on 2018's General Election of Tulungagung
}

\author{
Mohammad Darry ${ }^{1} \&$ Panji Anugrah Permana ${ }^{2}$ \\ \{mohammad.darry@yahoo.co.id ${ }^{1} \&$ panji.anugrah@gmail.com² ${ }^{2}$, \\ Universitas Indonesia, Indonesia ${ }^{1}$ \\ Universitas Indonesia, Indonesia ${ }^{2}$
}

\begin{abstract}
This article analyzes the role of botoh and village head as a political broker in Tulungagung District Election on 2018 by focusing on the victory of Syahri MulyoMaryoto Birowo. Through interviews with the candidate's winning team, I found that this victory was indivisible from the use of a network of political broker. Candidate use botoh and village heads as political brokers because they have loyalty and militancy in winning candidates even, they are not in favorable conditions because these candidates are only supported by one political party and Syahri Mulyo as the regent candidate before the election day was caught in a corruption case. Botoh and the village heads have personal closeness with the candidates which cause the relationship pattern being unmaterialistic. The findings of this study explain the relationship pattern of political broker with the candidates that effected on interrelationship as the botoh are given with convenience and access while the village heads is assited by the candidate's victory, so they are indebted to winning the candidate. Besides that, the relationship between the candidate and the broker is not done directly, but through another team that accomadates the botoh and the village head. In local election the use of political brokes is not only exists as single entity but also forms a diverse network.
\end{abstract}

Keywords: Local Election, Political Broker, Botoh, Village Heads.

\section{Introduction}

The utilization of broker is part of the winning strategy for the candidate in the regional election. These brokers, as part of non-formal winning team, have position as patron in the society and have a good understanding about voters in some area. The candidates not only have to ensure the distribution of goods and services for their voters, they also have to set up a seat for those brokers. While the incumbents use their capabilities to distribute public resources as an exchange tool when it needed [1]. In line this phenomenon happens, these brokers exist as the associates of individual with strategic resources such as head of region and have close relationship with them.

Study about some regional elections, for example Tanah Laut District on 2013, Takalar District on 2007, and The Province of Jambi on 2010 indicates the use of political broker to win the candidates [2][1]. The use of broker based on the fact that someone who join the contest make clientelistic strategy to understand the root of the voters with aim to give what is necessary for their voters. These brokers, with their social network, play a role to provide the 
understanding and insight about the voters for the political candidates which can be used to gain the vote of these candidates. There are a reciprocal benefit between the candidates and the brokers that will bring advantages for the brokers, both material and non-material.

In Indonesia, the case of broker's utilization on general election has being a common sense, however on the case of Tulungagung's regional election there are some diferences. The utilization of brokers as an effort to win both Syahri Mulyo - Maryoto Birowo caused by two unfavourable conditions: the lack of support from the political parties for those candidates and the stipulation of Syahri Mulyo as suspect on corruption which issued by the Corruption Eradication Commission (KPK) before the election day. Therefore, the candidate not only use political cadre as their election winning team, but also botoh and head of villages as their political brokers. These botohs are people who gambling their chances on the election of the head of villages, which means they have interest to win one of the candidates they are supported with to win the stake using all the winning strategy they have. These botohs are an opportunist people and have no bond ideologically. On the other side, head of villages are obligated to gain the symphaty and to mobilize the people.

This writing is trying to explain about the role of botoh and head of villages as political broker in the case Tulungagung's Regional Election with the winning o Syahri MulyoMaryoto Birowo as the case. The phenomenon of botoh and head of villages as political broker shows the importance of strong explanation about the work for winning the candidate despite on the unfavourable condition. There are two type of brokers in the context regional election which caused on the differences of role to gain the vote. The candidates use both head of villages and botoh to be the political broker because they have different roles to play depends on their capabilities. Therefore, that differences show the relation between the winning of Syahri Mulyo-Maryoto Birowo on the Tulungagung's Regional Election on 2018 with the political broker, not only as a simple plot but also as a complex relationship between the candidates as the broker is not a single entity but also as plural and gradual entities.

\section{Research Methods}

This research will focus on the region of Tulungagung with the context on Regional Election of Tulungagung on 2018. This research also is going to use quantitative method as a tool to expose a social symptom. This research is using literature review at the beginning and it contains explanation on theory and concept about the appearance of broker as part of political machine and his role. The result of the literature review will be used as reference for the writer to formulate research question and primary data collection through in-depth interview.

With the using of qualitative method, the data that are being collected later will be evaluated using a detail and comprehensive depiction to get the meaning behind all the data. By using this method, the writer can get involved on social setting which in line with the goal of the research, which make the writer can observe the object in their daily activities and getting involve with them [3]. There are some reason behind the utilization of this method: first, it make the field adaptation will be easier especially when it comes with the fact; second, this method providing direct essence between the researcher with the source/ informant, and third, it is more sensitive and quick adaptable with many of influence and toward the patterns of the values that being faced [3].

\section{Clientelism and The Role of Political Broker}


This research uses the concept of clientelism which develop by Susan Stokes (2013) [4] and the theory of broker's role from Rodrigo Zarazaga (2014) [5]. Stokes already explain that the appearance of the broker happens as effect of the political party's needs to ensure the distribution of resources are matching with their target and to ensure the voters are voting for the party or the candidate itself. On the other side, the theory of broker's role from Zarazaga will be used to analyze the role of broker during the political campaign of Syahri MulyoMaryoto Birowo on the Regional Election of Tulungagung on 2018.

Clientelism is a strategy which runs by the political machine to win the candidate, but they need to be ensured wether the distribution of resources will affect on the electability of the candidate. To see the appearance of the broker, this concept is being used by Stokes (2005) [6] on his research and findings in Argentina. Stokes has already show that clientelism can be successful if the political machine doing a monitoring strategy to make sure the distribution of resources will make the voters are being loyal to the candidate. Therefore, the political machine needs to form a structure in the level of community to make some people with specific characteristic to be recruited and employed.

The candidates need the broker's network to distribute his resources to their voters, while on the other side, the broker need the candidate to gain the incentives. These caused on the simbiotic relationship between the two. As broker also have maintains the relation with his client and the clients also already realize that the broker is utilized to fulfil their daily needs. That is why the broker's choice of his support for the candidate has impact on his client and if the candidate is wins, it will raise the status of the broker in his community. On the other side, if they are being loyal to one of the candidate, it will help them to seat on strategic position as promised by the candidate [7]. And if he betrays the candidate, it might be caused on the losing of the position in the next election and he will lose the trust.

The analysis using the role theory from Zarazaga (2014) [5] stated that the broker, not only have a role to gain the votes through provision of goods and services, but also act to campaign just like the candidate. To understand more about the role, this research will use the roles of brokers during the electoral process: first the broker as propaganda activist, mass mobilization and to gain the votes. These three roles of brokers are being used to see the involvement of botoh and head of villages as a political broker during the campaign of Syahri Mulyo-Maryoto Birowo. With that assumption, this research will analyze the importance of botoh and head of village's role as part of Syahri Mulyo-Maryoto Birowo political machine which end the winning of these candidates during the Regional Election of Tulungagung on 2018. This research are going to see whether they are using those three roles simultaneously or only one of them and is that any other variant that exist on his role.

\subsection{The Head of Villages Role as Propaganda Activist}

When Syari Mulyo is being arrested, just about 21 days before the elections day, it leads to the move over of the support within the society. It also leads to the confusion within the grass roots as Syahri Mulyo is successfully brand his persona as a populist and anti-corruption figure. But his arrestment made him need to rebuild his own persona and to formulate new campaign strategy. At this moment, the head of villages act as propaganda activist which influence the society to put their choice still on Syahri Mulyo-Maryoto Birowo. There are three technique of propaganda which being used by the head of villages to win those candidates. 
First, the head of vilages gave information that the arrestment of Syahri Mulyo was a political scenario from his opponent. Margiono was reputed using his network as national figure and his background as head of PWI's main office to set up Syahri Mulyo. Second, the head of villages are giving information that stated the probability of Syahri Mulyo to back to Tulungagung if he win the election and being inaugurated. This phonemenon bring up the term of banteng ketaton in the society. This propaganda lead to the increasing of enthusiasm to win Syahri Mulyo so it will bring him back again to Tulungagung. Third, the head of villages explain to their people that they need to win those candidates as compensation for the continuity of villages empowerment program.

\subsection{The Role of Botoh as Mass Mover}

Syahri Mulyo believes botoh as a consultant with political capabilities. This happens as result of elections on 2013 and 2018 where botoh show their capabilities despite the Syahri Mulyo's unfavorable conditions at that time. Syahri Mulyo consider the presence of botoh as the part of winning strategy is way far more effective than the structure of parties. Based on Tilly (2005), the politician use some of "trusted network" to appeal a help with attention or assistance from someone else. That kind of network can be a good political base as all the obligation, intimacy, and social control that appear from such things can facilitate a clientelistic exchange.

Mobilization acted by botoh is based on structural level, each botoh that sean on sub district level have structural bond with botoh on village's level. Botoh on the level of RT / Neighborhood Association, could mobilize at least 10 people using many tools to attract them, such money, present, or another type of allurement. Each botoh are targeted to invite $70 \%$ or 7 people to join the campaign. The motive of this method is based on kinship, association's network, etc (Kurniawan, 2019).

The involvement of these botoh is being recognized to assemble a real mass. Traditionally, these botoh can ensure the number of voters obtained in a single village with a high number of accuracy. This method, used by Syahri Mulyo, is more effective than using the political consultant's services that need a heavy start with huge number of financing. Based on that consideration, the utilization of botoh is being choosed as they have experience and managable networks.

This network of botoh formed by Syahri Mulyo and Supriyono are usable and can be utilized as they always can fulfill the needs of their botoh. These types of relations lead to inseparable bond amongs them. In unfavorable condition, the botoh will set their support for Syahri Mulyo-Maryoto Birowo as proven from the main campaign that held after the arresment by KPK. This political success based on the capacity of relationship with social network that can be used and meaningful for the voters. Those things will run effectively as a result of the appearance of respectful figure in both of those botoh's network, Dasar, as father of Syahri Mulyo and Suharminto, brother of Supriyono.

\subsection{The Role of Botoh as Gain Voters}

These botoh are able to change the course of election with their assistance to gain the votes, even if the candidate was not in a favourable condition. First, these botoh are giving a specified amount of money which depends on the loyality to the candidate or preferrably known as ngebomb. Second, these botoh are collecting data and mapping the information 
about supporters of those candidates, Syahri Mulyo-Maryoto Birowo or Margiono-Eko Prisdianto, and all the voters that have no choices yet. To understand the exact time and the amount of money that should be allocated, these botoh are doing a specific data collection for even every single detail about it. Third, these botoh are using another way beside the usement of money to gain more votes for Syahri Mulyo. First, they buy the invitation letter of Margiono-Eko Prisdianto's voters so they can't participate in the election. Second, they exchange the letter with presents and holiday trips during the elections day.

Those methods are successfully implemented by these botoh because of some supporting conditions. First, this effort is being supported by the cultural conditions within the society. Adib Makarim explains that there is some opinion on the society that see the program as elite's matters. The most important thing is they got the money from the candidates. Botoh are using this to give money to the grass root society as the society tends to choose the candidate with money. Second, is from the side of Margiono where he believes that the issue of corruption that implied on Syahri Mulyo makes Margiono believe he can be a single winner without cost of money. The socialization of his vision and mission and his programs as a clean persona lead to no attractiveness from the society. Third, there is an issue of the giving of money will be delivered by Margiono are developing in the society but it never happens. While Syahri Mulyo is still increasing the amount of money they gave to.

\section{Conclusion}

The role of botoh and head of villages as political broker are very important toward 21 days before the elections day on June 27th 2018. There are indeed a differentiation between head of villages and botoh's role based on theory of political broker's role from Zarazaga. There are three different roles that can be run by each entity, head of villages as propaganda activists, botoh with their role as mass mobilizer and to gain more votes. In the practical stage, the roles of the three of them are effectively being done.

First, head of villages can act as propaganda activist to influence with three narration of reasoning to stay put their choice on Syahri Mulyo-Maryoto Birowo. First, the arrestment of Syahri Mulyo as political scenario of Margiono, which is a national figure, successfully brand Syahri Mulyo as "political victim". Second, the explanation on how all the empowerment program on villages will be revoked if Margiono chosen. Third, the statement on the winning of Syahri Mulyo will be freed from all charges and will bring him back to Tulungagung.

Second, there are two types of botoh's network that being used to play a role on mass mobilization, the network of Syahri Mulyo and network of Supriyono. Those networks are consisting of influentional senior figures with Dasar on Syahri Mulyo's network and Suharminto on Supriyono's network. The possibility of the mobilization was a result of the assistance from those figures for the botoh. This impacted on the feeling of hesitate and embarassment from the botoh to those figures and make them are willing to mobilize their mass to choose Syahri Mulyo

Third, the role of botoh as buying votes has impact on the winning of the candidate. This effort is being done by using two types of methods: by giving a certain amount of money to the voters with their invitation as the exchange or by inviting the voters on holiday trips. This role is being supported by the strategy to formulate a structural network from the level of subdistrict to subvillage that assisting to decide when or whom the money and the goods are being given suitably with the target which at the end, lead to effectively gain more voters. 


\section{References}

[1] L. Agustino, "Patronase Politik Era Reformasi: Analisis Pilkada Di Kabupaten Takalar Dan Provinsi Jambi," J. Adm. Publik, vol. 11, no. 2, 2014.

[2] E. Aspinall and M. U. As'ad, "The patronage patchwork: Village brokerage networks and the power of the state in an Indonesian election," Bijdr. tot taal-, land-en volkenkunde/Journal Humanit. Soc. Sci. Southeast Asia, vol. 171, no. 2-3, pp. 165 195, 2015.

[3] H. Lisa, "Metodologi Penelitian Politik," Jakarta Kencana Prenada Media Grop, 2007.

[4] S. C. Stokes, T. Dunning, M. Nazareno, and V. Brusco, Brokers, voters, and clientelism: The puzzle of distributive politics. Cambridge University Press, 2013.

[5] R. Zarazaga, "Brokers beyond clientelism: A new perspective through the Argentine case," Lat. Am. Polit. Soc., vol. 56, no. 3, pp. 23-45, 2014.

[6] S. C. Stokes, "Perverse Accountability: A Formal Model of Machine Politics with Evidence from Argentina," Am. Polit. Sci. Rev., vol. 99, no. 3, pp. 315-325, 2005.

[7] G. T. I. Tawakkal, "Gapit: Jaringan Mobilisasi Suara di Pilkades," Polit. Indones. Indones. Polit. Sci. Rev., vol. 2, no. 1, pp. 30-45, 2017. 